\title{
Fuzzy Energy Management Scheme for a Hybrid Power Sources of High-Altitude Pseudosatellite
}

\author{
J. I. Corcau (iD) and L. Dinca \\ Department of Electrical, Energetic and Aerospace Engineering, University of Craiova, Craiova 200440, Romania \\ Correspondence should be addressed to J. I. Corcau; jcorcau@elth.ucv.ro
}

Received 31 January 2020; Revised 12 July 2020; Accepted 27 August 2020; Published 18 September 2020

Academic Editor: Luis Carlos Rabelo

Copyright (c) 2020 J. I. Corcau and L. Dinca. This is an open access article distributed under the Creative Commons Attribution License, which permits unrestricted use, distribution, and reproduction in any medium, provided the original work is properly cited.

\begin{abstract}
HAPS (high-altitude pseudosatellites) are flight machines, airplane type, generally without pilot which fly in a definite zone at 18$22 \mathrm{~km}$ altitude, providing communication and surveillance services. These flight machines do not leave the atmosphere, and their purpose is to maintain a constant flight level for as long time as possible in the interest zone (e.g., five years) to fulfill their mission. HAPS energetic system proposed in this paper has to feed the electric propulsion system of HAPS (12.5 kW) and also to feed onboard equipment (navigation, data links, scientific equipment, etc.). On-board energy sources have to maintain HAPS in the interest zone for long periods. For this reason, it is used in the present solar power sources. A part of the generated energy is consumed on board; the rest is stored daytime and consumed nighttime. So, the system is provided with energy generation systems and also with storage and management systems. HAPS energetic system is a hybrid type, with two or more power sources. In this case, power sources are photovoltaic panels are used daytime and fuel cell are used nighttime, and also, a battery and/or a supercapacitor is used in transition periods from day to night and in peak load periods. In this paper, an electric power system used nighttime is designed and analysed. In this situation, the primary power source is the fuel cell and the secondary power sources are battery and/or supercapacitor. There are used numerical simulations models, developed in Matlab/Simulink, for all hybrid power source components: fuel cell stack, battery system, supercapacitors, conversion system, and fuzzy logic power management system. For a part of these components, there are used existing simulation models in Matlab/Simulink, adapted to these simulation requirements, and for others, there are designed and implemented simulation schemes according to these simulation requirements. An important component of the hybrid power source is the power conversion system which adapts the power sources parameters to consumer input requirements. A fuzzy logic power management system is designed.
\end{abstract}

\section{Introduction Pseudosatellite Utility}

High-altitude pseudosatellites (HAPS) are UASs (Unmanned Aircraft Systems) recently considered by the big aviation companies as Boeing and Airbus and also by spatial agencies NASA and ESA. Their goal is to replace the communication and surveillance services provided by classical satellites which are very expensive with services provided by cheaper technological platforms. Communication and surveillance devices will be transferred on UAVs (Unmanned Aerial Vehicle) flying about $20 \mathrm{~km}$ altitude. These solution advantages are many and different: flight machine can be easily grounded for maintenance and equipment update; flight machine is usable for many flights; production and exploita- tion costs for these UASs is incomparably smaller than costs for classical satellites; surface covered for a HAPS flying at $20 \mathrm{~km}$ altitude can be one of $1000 \mathrm{~km}$ diameter if UAS flies on a circular trajectory of $2 \mathrm{~km}$ radius; HAPS stratospheric flight is very convenient due to turbulences absence, so the propulsion power required to maintain an imposed trajectory is very small; UAS structure stresses in condition of turbulence absence and constant flight are very small, so the structure can be very lightweight; solar radiation at $20 \mathrm{~km}$ altitude is higher than ground level, so it can generate more electric power with photovoltaic devices, in the absence of high energy radiation in extra-atmospheric flight, which can disturb on-board electronic devices; and flight at $20 \mathrm{~km}$ altitude is performed at $1 \mathrm{~g}$, not in imponderability conditions 
which is an important advantage for some on-board devices like regenerative fuel cell.

Worldwide, the possibility to obtain a flight machine usable as HAPS was studied starting the 1980's but developed especially after 2010. In the 1980 's, Condor project from Boeing (see Figure 1(a)) developed in the DARPA program frame to evaluate technological possibilities for HighAltitude Long Endurance (HALE) flight. There are used internal combustion engines, light composite material structure, low Reynolds number flight, autonomous operation, stopped engine temporary flight, and after mission landing. It can reach $22300 \mathrm{~m}$ altitude and $58 \mathrm{~h}$ autonomy [1].

Titan aerospace was tested in August 2013, a concept vehicle $11 \mathrm{~m}$ span, for the future high altitude UAV SOLARA 50 (see Figure 1(b)) and SOLARA 60. SOLARA 50 was expected to fly in 2014. Design performances were $21500 \mathrm{~m}$ ceiling, $100 \mathrm{~km} / \mathrm{h}$ maximum speed, and $35 \mathrm{~kg}$ payload. SOLARA 50 was designed as a $54.7 \mathrm{~m}$ span airplane with wing and stabilizer extrados and also all fin covered with 3000 solar cells. For night flight, Li-ion was used for wing stored batteries. The maximum flight time for SOLARA 50 is expected to be 5 years. It will be equipped with telecommunication and surveillance systems and also with atmospheric sensors. For SOLARA 60, a $125 \mathrm{~kg}$ payload is expected [2,3].

The Phantom Eye project (see Figure 1(c)) uses internal combustion engines fed with cryogenic stored hydrogen. The payload is expected to be between 500 and $1250 \mathrm{~kg}$ with 7 to 10 days flight time at a minimum of $20000 \mathrm{~m}$ altitude. One can monitor surfaces with $1000 \mathrm{~km}$ diameter in a circular flight path with $2 \mathrm{~km}$ radius. Other performances are $50 \mathrm{~m}$ span, $17 \mathrm{~m}$ length, $4000 \mathrm{~kg}$ empty weight, $225 \mathrm{~kg}$ payload, $5000 \mathrm{~kg}$ take-off weight, 2 Ford engines of $2.3,1.4 \mathrm{~m}$ propeller diameter, and light composite glued material structure [4].

Boeing High-Altitude Long Endurance (HALE) UAS2012 follows to develop UAS for high altitudes designed for transmission links in infrastructure failure conditions and for long time surveillance of interest areas.

The Zephyr 7 project for HAPS from Airbus Defence \& Space will be used for surveillance, communication, and monitoring services on surfaces about tens of thousands $\mathrm{km}^{2}$. It owns the longest flight record-336 hours in July 2010, performed on wintertime at Great Britain latitude, when day is considerably shorter than springtime [5]. It uses solar energy propulsion and Li-ion battery storage with $3 \mathrm{kWh}$ capacity for nighttime propulsion. It has a carbon fibre structure; $22.5 \mathrm{~m}$ span; $53 \mathrm{~kg}$ weight; $2.5 \mathrm{~kg}$ payload; 2 asynchronous motors with permanent magnets, $0.45 \mathrm{~kW}$ each; $56 \mathrm{~km} / \mathrm{h}$ cruise speed; and a 21000 practical ceiling. Zephyr 8 version was expected to have $28 \mathrm{~m}$ span and to fly in 2016. As it can be observed, propulsion solution varies from internal combustion engine with cryogenic store hydrogen for Phantom Eye to electric propulsion using solar energy stored in Li-ion batteries for night flight at SOLARA 50, SOLARA 60, and ZEPHYR. The Solar Eagle project follows to use solar energy from photovoltaic cells at daytime and hydrogen produced by SOFC fuel cells at nighttime.

The Solar Eagle project from Boeing will use high-efficiency, low-weight solar cells and hydrogen energy storage for SOFC fuel cells. Its span will be $120 \mathrm{~m}$ and will use 6 permanent magnet electric motors [6].

Sustainable development gained an important role in the future civil transport aircraft generation. Solutions which use ecologic power sources such as hydrogen fuel cells are already studied. In this context, the European Commission chose to develop the sixth Aeronautica and ENFICA FC project (Environmental Friendly Inter City Aircraft powered by Fuel Cells). The project's goal was the following: a feasibility study concerning the development of new and innovative energetic systems, based on fuel cells. To reach this goal, a 2-seat conventional airplane with energetic systems entirely based on fuel cell is used. In this direction, a feasibility study was performed to obtain more preliminary information concerning systems design (APU-auxiliary power sources, main electric systems, emergency electric systems, landing gear, and so on) where fuel cells (PEM or SOFC) could be used. Feasibility study takes into account the present development level in fuel cell applications for aviation and a comparison between fuel cells used for a conventional airplane and those used for an electric plane. It also presented the feasibility of a 10-15seat electric commercial airplane entirely feed from fuel cells. In this study, the sets and flight tests of an aircraft using hydrogen fuel cells are also presented. During a flight test, the entire electric system is studied. It obtained a record speed of $135 \mathrm{~km} / \mathrm{h}$ during a 39 -minute flight. During the 6 flight tests, $2.5 \mathrm{~h}$ and $237 \mathrm{~km}$ were covered [7].

Boeing develops a feasibility study concerning noise and pollutant emissions of transport aircraft, using fuel cell technology. Boeing Research and Technology Europe (BR\&TE), Spain, developed and tested in April 2008, near Madrid, the first electric motor glider Super Dimona of $770 \mathrm{~kg}(850 \mathrm{~kg}$ with fuel cells) and $16.3 \mathrm{~m}$ span. BR\&TE modified the glider to incorporate a PEM fuel cell and a hybrid Li-ion battery and to feed a $40-\mathrm{kW}$ electric motor acting as a conventional propeller. The pilot took off and climbed to $1000 \mathrm{~m}$ using a battery system and the fuel cell and after that flew straight line for $25 \mathrm{~min}$ with $100 \mathrm{~km} / \mathrm{h}$ using energy produced by a fuel cell [8].

Airbus conducted the European project CELINA (Fuel Cell Application in New Configured Aircraft) and had the following targets: define minimal requirements in fuel cell service, installing and maintenance of these innovative systems, a fuel cell system design and its specific subsystems, fuel cell performance evaluation, and fuel cell integration in existent systems. Airbus and DLR presented the first commercial airplane fuel cells fed in ILA Berlina Air Show 2008. The most recent researches in the domain were performed on an Airbus 320 which used fuel cell systems [9].

DLR used in June 2009 a motor-glider ANTARES-DLR$\mathrm{H} 2$ which took off using fuel cell energy. The fuel cell maximum power was $25 \mathrm{~kW}$ from the entire system energy, and the glider could maintain a constant flight level with about $10 \mathrm{~kW}$ from a high-temperature PEM FC. Total efficiency from hydrogen tank to propeller was about $44 \%$-twice than a conventional piston engine [10].

AeroVironment developed the Global Observer UAV program for aerial space monitoring. This program intended to combine extreme flight time (more than 5 days continuous 


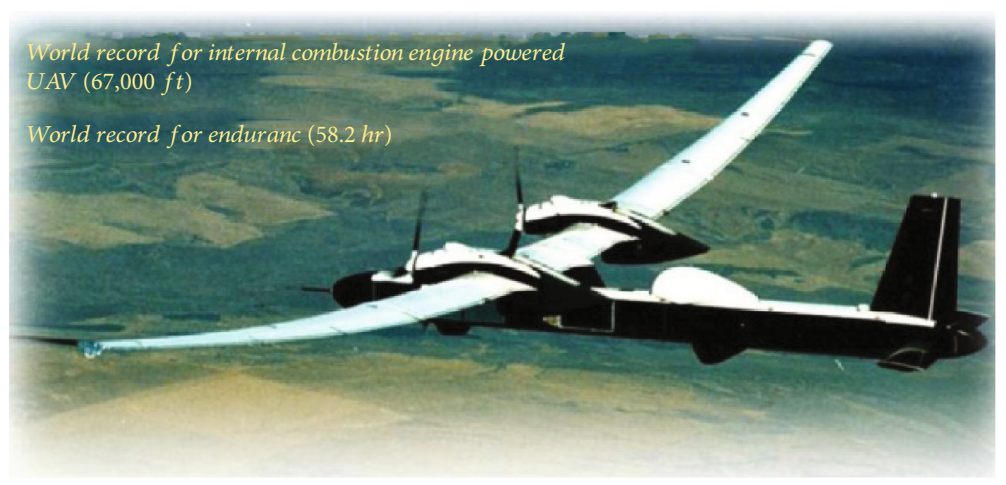

(a)

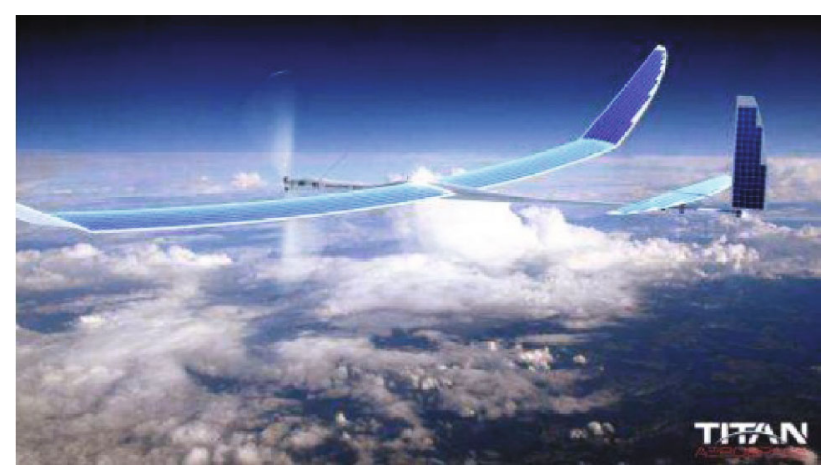

(b)

Phantom eye demonstrator configuration

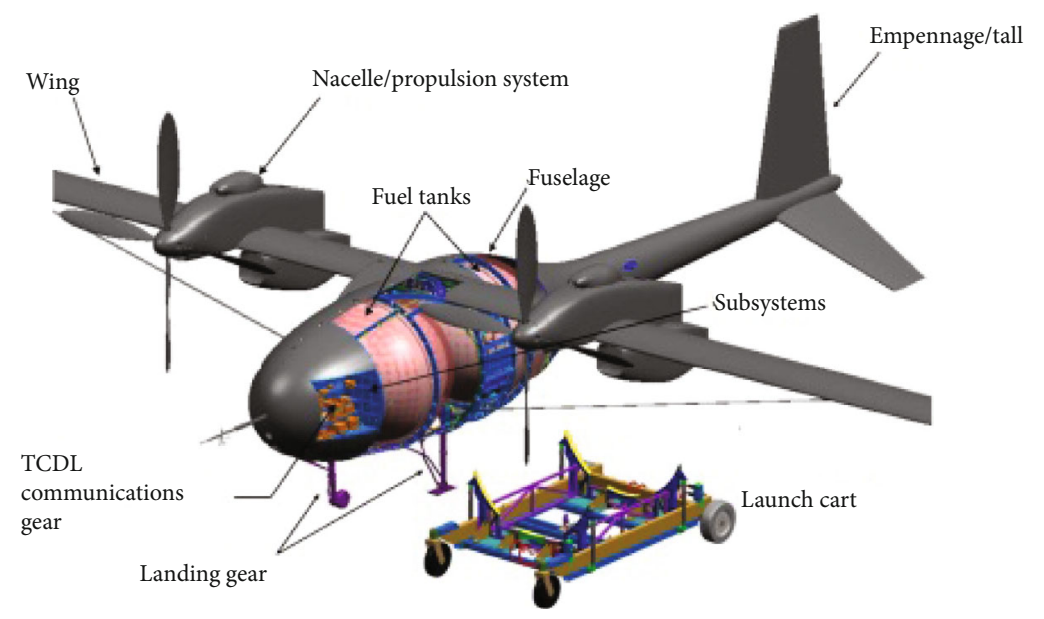

(c)

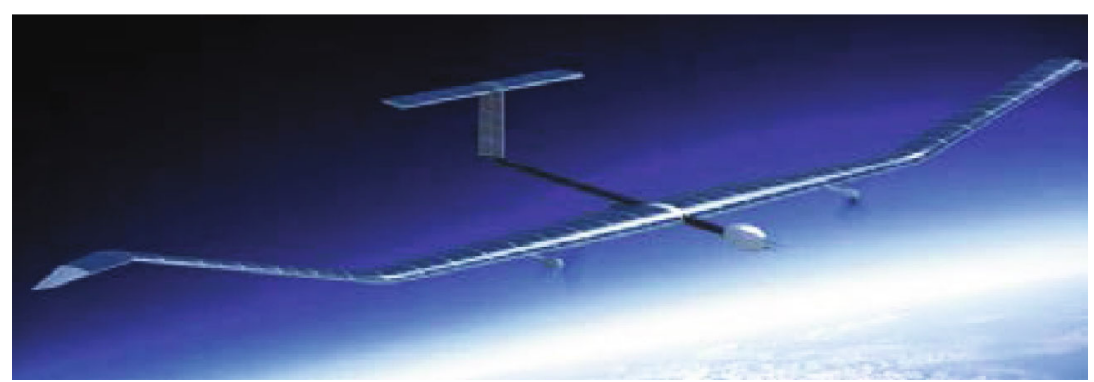

(d)

Figure 1: Pseudosatellite utility. 


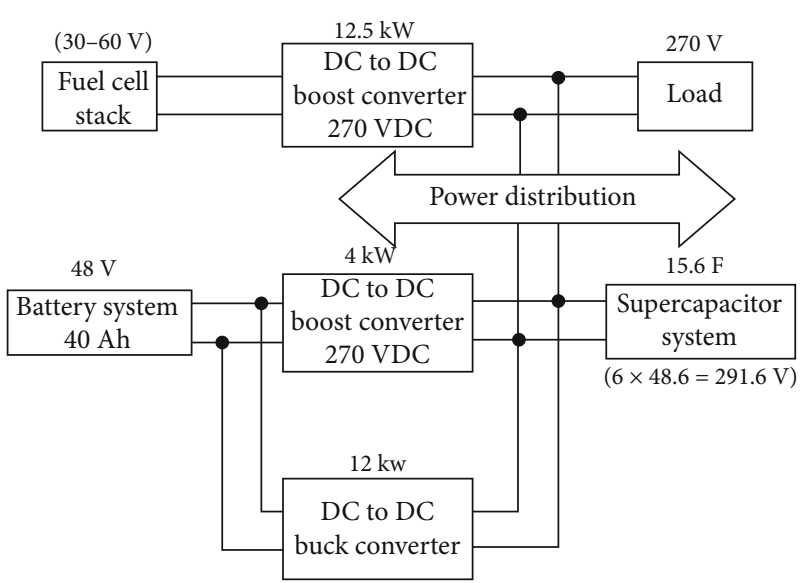

FIGURE 2: Block diagram for power system on-board HAPS.

flight) with stratospheric flight, with low costs, flexibility, high space covering, and safety. Global observer UAS used for the first time an electric propulsion aircraft fed from liquid hydrogen-based fuel cells. On 11 January 2011, the flight lasts 4 hours $[1,11]$.

It observed the intention to develop propulsion systems for unlimited flight (about 5 years for Solar Eagle). These systems use hybrid regenerative energetic systems to store electric energy produced by solar panels at daytime and its reuse at nighttime. In present, functional solution stores energy in Li-ion batteries with an energy density of about $210 \mathrm{Wh} / \mathrm{kg}$ (about $756 \mathrm{~J} / \mathrm{g}$ ). But flight time with this system is 336 hours (14 days). A long-term alternative is switching to hydrogen fuel cells (see the Solar Eagle project) $[6,11]$.

Another project presented in the same direction is the project StraVARIA. In the project StraVARIA, the goal was to develop a high-fidelity multiphysical simulation of such a HAPS, including a long-term mission planner, a reactive guidance system for weather avoidance, a flight control system with protections, a 6-DoF (Degrees of Freedom) model with a solar-electric propulsion system, and a comprehensive environment simulation with 4-D wind and turbulence [3].

In present, fuel cells are interesting for their high efficiency and low pollutant emission characteristics. Supposing a clean hydrogen production, fuel cells have a high number of advantages compared with classic power sources: high efficiency, especially when cogeneration is used (electricity and heat); noiseless; and without greenhouse gas emissions. This is the reason why the European Union decided to invest a significant amount of money in research projects concerning fuel cells and hydrogen [12].

High-pressure fuel cells need auxiliary devices to control gas flow through fuel cell stack. Due to these auxiliary devices, fuel cell dynamic performances could be limited and it is a necessary power buffer to sustain load power peaks. Moreover, hybridisation has a beneficial effect concerning system dimensions and reduces weight and volume for the entire system. Hybridisation offers many possibilities in system design regarding architecture and power management. A hybrid system designer will decide how to connect power sources, number, and management strategy for power converters, to adapt power source parameters to load require- ments. Management strategy will be in concordance with electric network requirements, and volume, weight, and costs have to be minimum.

1.1. HAPS Power System. The HAPS hybrid energetic system was designed using a complementary advantage principle. It consists of power sources: fuel cell as a primary electric power source (components of energy production), battery system, and/or supercapacitors as a secondary power source (components of energy storage) for HAPS. This configuration with three power fluxes is presented in Figure 2.

The dynamic characteristics of the three power sources lead to a more complicated hybrid system. Consequently, it is essential to provide an efficient power management. Management strategies determine power allocation between different sources and improve the energetic efficiency and hybrid system lifetime. The energy stored in the battery systems and in the ultracapacitor provides a double benefit: preserving the life of the fuel cell and achieving a better dynamic response to load variations $[13,14]$.

The objectives of this hybrid configuration are as follows:

(i) Minimization of hydrogen consumption [15]

(ii) Protection of the fuel cell from fast transitions of the load

(iii) Storage of energy in a battery-ultracapacitor assembly

(iv) Maintaining power over the load within the prescribed limits

\section{Design and Modelling of PEMFC}

Although presented in literature and mass media as a new scientific and engineering domain, this technology was invented since the XIX century (i.e., 1839 William Grove). For more than a century from their discovery, fuel cells were presented and studied only as a curiosity, either in experimental laboratories or for general public astonishment. This until 1960 when fuel cell potential was valorised by NASA in spatial programs Gemini and Apollo, as a viable alternative to other power sources, either more expansive (solar panels) or with high risks (nuclear energy) [16]. Fuel cell commercial development is expected for another three decades.

A fuel cell is a converter for the fuel energy in electric energy by chemical processes. Fuel cell simplicity and efficiency focused on-in the beginning by curiosity and then by necessity - considerable scientific efforts which led to their diversification: Alkaline Fuel Cells (AFC), Proton Change Membrane Fuel Cells (PEMFC), Phosphoric Acid Fuel Cells (PAFC), Carbonate Melting Fuel Cells (MCFC), Oxide Materials Fuel Cells (SOFC), and so on [17].

Choosing one fuel cell or another for an application is led by the fuel cell parameters (i.e., work potential) and used fuel (i.e., hydrogen+oxygen or methane or carbon dioxide, and so on). Each fuel cell has already a specific application field. Although, in order to use one fuel cell with zero pollutant emissions, PEM fuel cells are the leaders especially due to the reaction product which is water. Water can be used 


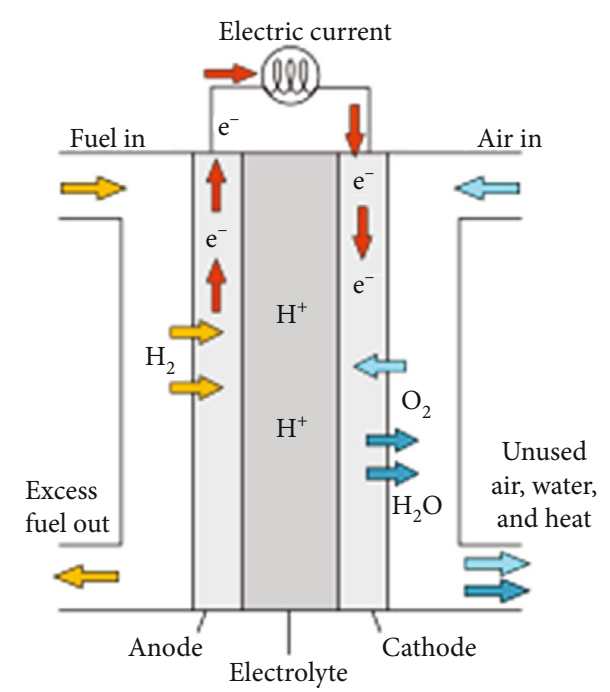

Figure 3: PEMFC-proton change membrane.

directly as a reactant in the reverse process-electrolysis-to obtain hydrogen and oxygen. This possibility is essential in applications where hydrogen and oxygen resources are limited, as in orbital stations or spatial exploration programs.

PEM fuel cells (in Figure 3) have many advantages: (i) they can operate at relatively low temperatures, so it is possible a better thermal control; (ii) they have a low volume; and (iii) they have a high gravimetric density. For these reasons, they are preferred in machine building, portable devices, and spatial applications. For example, the PEM fuel cell market is about $90 \%$ from automotive requirements.

Electrochemical reactions take place at the membraneelectrode interface. Hydrogen (gas), introduced to one fuel cell port, is dissociated at the membrane-electrode interface in its constituents (two protons and two electrons); this process is catalysed with Pt. Protons diffuse further through membranes and are transported to the other interface membrane-electrode. The resulted electrons from hydrogen dissociation are collected and transported in the external electric circuit, where they can produce mechanical work. At the second interface, proton oxidation occurs in the presence of a reducing agent (gas oxygen) and electrons from an external circuit. The reaction product is water which is eliminated by a continuous flow of oxidant agent (oxygen or air).

Overall, the theoretical energetic balance for the electrochemical cell (as it results from oxide-reducing potentials referred to hydrogen electrode) is equivalent to $1.23 \mathrm{~V}$ (or theoretical potential of the hydrogen fuel cell). Assuming the entire free Gibbs energy is converted into electricity, the maximum theoretic efficiency of a PEM fuel cell is about $83 \%$. In practice, only a part of this free energy is transformed into electricity, and another part is lost as heat in electronic transport processes (ohm losses) or along the protonic membrane, at the interface with membrane and gas diffusion porous layer (GDL). Detailed studies concerning ohm losses in PEM fuel cells reveal 35\% greater losses, so in an optimistic scenario, hydrogen conversion in electricity has a maximum efficiency of about $53 \%$. By consequence, in order to improve PEM fuel cell efficiency, one has to reconsider membrane-
TABLE 1: Fuel cell model parameters.

\begin{tabular}{lc}
\hline Fuel cell model input parameters & \\
\hline Voltage at 0A and 1A [V_0(V), V_1(V)] & {$[52.5,52.46]$} \\
Nominal operating point [Inom(A), Vnom(V)] & {$[250,41.15]$} \\
Maximum operating point [Iend(A), Vend(V)] & {$[320,39.2]$} \\
Number of cells & {$[65]$} \\
Nominal stack efficiency (\%) & {$[50]$} \\
Operating temperature (celsius) & {$[45]$} \\
Nominal air flow rate (lpm) & {$[732]$} \\
Nominal supply pressure [fuel (bar), air (bar)] & {$[1.16,1]$} \\
Nominal composition (\%) [H2 O2 H2O(air)] & {$[99.95,21,1]$} \\
\hline
\end{tabular}

electrode ensemble architecture, both in the manufacturing process and costs reducing, especially using a lower catalyst (Pt) loading per $\mathrm{kW}$ obtained energy (e.g., target imposed by the Department of Energy (DOE) which is about $0.2 \mathrm{~g}$ $\mathrm{Pt} / \mathrm{kW}$, in present, 0.3-0.4 g Pt/kW [17].

Two fuel cell types are used in aeronautics: PEM (proton exchange membrane) and SOFC (solid oxide fuel cell).

High-temperature fuel cell $\left(100-200^{\circ} \mathrm{C}\right)$ has some advantages than low-temperature fuel cell $\left(50-80^{\circ} \mathrm{C}\right)$, only to PEM fuel cells, as lower $\mathrm{CO}$ absorption from catalyst produces a lower CO catalyst contamination and so the efficiency increases, surface with lower heat exchanges has to dissipate heat excess, and electrochemical reaction product, water, is easily evaporated at higher temperatures, so the water management is easier.

Moreover, it is known that for mobile applications, fuel cells have to work at $120^{\circ} \mathrm{C}$ with low relative humidity, and for stationary applications, they required a higher temperature than $150^{\circ} \mathrm{C}$. For this reason, a high temperature and relatively high humidity membrane are critically necessary.

In present, the most important problem concerning fuel cells in aeronautical applications is energy density which is about $700-2000 \mathrm{Wh} / \mathrm{kg}$ but one estimate is to rise up to 10 $\mathrm{kWh} / \mathrm{kg}$ in the following $10-15$ years and up to $20 \mathrm{kWh} / \mathrm{kg}$ in 20-30 years. Even hydrogen has a high power density of about $120.000 \mathrm{~kJ} / \mathrm{kg}$, three times greater than kerosene $(42.800 \mathrm{~kJ} / \mathrm{kg})$, very low hydrogen gravimetric density leads to cryogenic pressurized tanks, which are very bulky and heavy. Particularly, it is an important gravimetric efficiency of hydrogen storage [18].

Hydrogen-based propulsion can be obtained in different ways: fuel cells feeding an electric motor, internal combustion engine $\mathrm{H}_{2} \mathrm{ICE}$, turbines, and hybrid motors (internal combustion engines, electromagnetic motors, and batteries).

Research results determined NASA to issue some research directions in hydrogen and oxygen PEM fuel cells to increase fuel cell performance in order to operate at higher current densities, without of thermal management unbalance risk due to ohm losses; investigate different packaging modules for power stacks in order to fit the volume and mass of APU boarding bay; confirm by many test reaction produced water is drinkable; find new materials to extend gaskets lifetime in oxygen fuel cells; investigate other working modes (with one end closed, recirculation, and so on); determine 

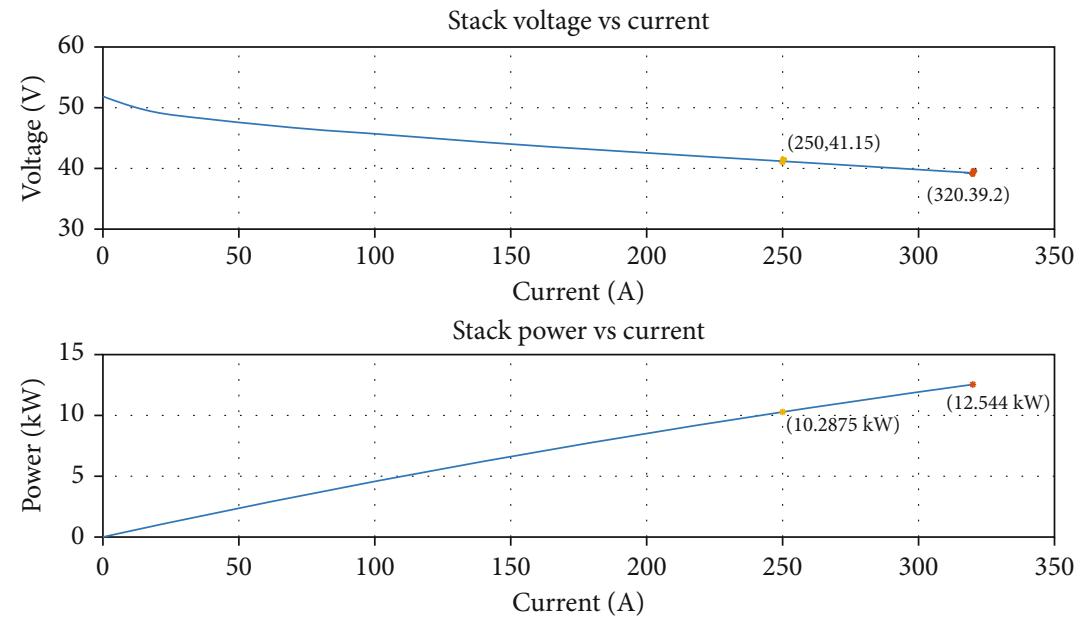

Figure 4: The dynamic behaviour of PEMFC.

the lowest reactant purity level and its implications in a longtime fuel cell management; and design, manufacture, and test a high power fuel cell (i.e., $20 \mathrm{~kW}$ ) for big aerospace applications, fitted in the APU system management [19].

This application was used as a default PEM fuel cell stack model from the Matlab/Simulink SimPowerSystems (SPS) Toolbox library. The Matlab/Simulink model implements a generic hydrogen fuel cell stack. The model consists of two options: a simplified model and a detailed model. The user can switch between the models by selecting the level in the mask. The fuel cell stack block implements a generic model parameterized to represent the most popular types of fuel cell stacks fed with hydrogen and air.

The simplified model represents a particular fuel cell stack operating at nominal conditions of temperature and pressure. To show the dynamic behaviour of a fuel cell stack, a Matlab/SPS model is presented. Table 1 shows the model of the fuel cell stack implemented in SPS Block, and Figure 4 shows the dynamic behaviour of a PEMFC. The stack is supplied by liquid hydrogen and compressed air.

\section{Design and Dynamic Modelling of Batteries}

In this case, it is used to simulate the lithium-ion battery pack. This type has high energy density and efficiency comparable to other battery types (such as lead-acid, NiCd, or NiMH). This makes them more attractive for aircraft applications.

The battery output voltage is given by [20].

$$
V_{\text {batt }}=E_{0}-K \frac{Q}{Q-\int \mathrm{idt}}-R \cdot i+A \exp \left(-B \int \mathrm{idt}\right) \text {, }
$$

where $V_{\text {batt }}$ is battery no-load voltage [V]; $E_{0}$ battery constant voltage $[\mathrm{V}] ; K$ polarization voltage $[\mathrm{V}] ; \mathrm{Q}$ battery capacity [Ah]; $\int i d t$ actual battery charge [Ah]; $A$ exponential zone amplitude $[\mathrm{V}] ; B$ exponential zone time constant inverse $[\mathrm{Ah}]^{-1} ; R$ internal resistance $[\Omega] ; I$ battery current $[\mathrm{A}]$.
TABLE 2: Battery model parameters.

\begin{tabular}{lc}
\hline Battery model input parameters & \\
\hline Maximum capacity (Ah) & {$[40]$} \\
Cutoff voltage (V) & {$[36]$} \\
Fully charged voltage (V) & {$[55.8714]$} \\
Nominal discharged current (A) & {$[17.3913]$} \\
Internal resistance (ohms) & {$[0.012]$} \\
Capacity (Ah) at nominal voltage & {$[36.1739]$} \\
Exponential zone [voltage (V), capacity (Ah)] & {$[52.3,1.96]$} \\
\hline
\end{tabular}

Table 2 shows the model of the battery implemented in SPS Block. The battery chosen for the simulation has the characteristics shown in Figure 5 and it is obtained from the model.

The state-of-charge (SOC) of the battery is between 0 and $100 \%$. The SOC is calculated as

$$
\mathrm{SOC}=100\left(1-\frac{Q \cdot 1.05}{\int \mathrm{idt}}\right)
$$

\section{Design and Dynamic Modelling of Supercapacitor}

Electric double layer capacitors (supercapacitors) are similar to conventional electrostatic or electrolytic capacitors, with the advantage that they can store or release more energy due to their high capacitance [21]. Compared to conventional capacitors with $\mathrm{mF}$ or $\mu \mathrm{F}$ capacitance, supercapacitors are designed to have a large electrode surface area and use high permittivity dielectric, therefore attaining very high capacitance ratings (up to $\mathrm{kF}$ ) [21]. The supercapacitor model implemented in SPS is based on the Stern model [19]. Table 3 shows the model of the supercapacitor implemented in SPS Block. Figure 6 presented the supercapacitor charge characteristic. 

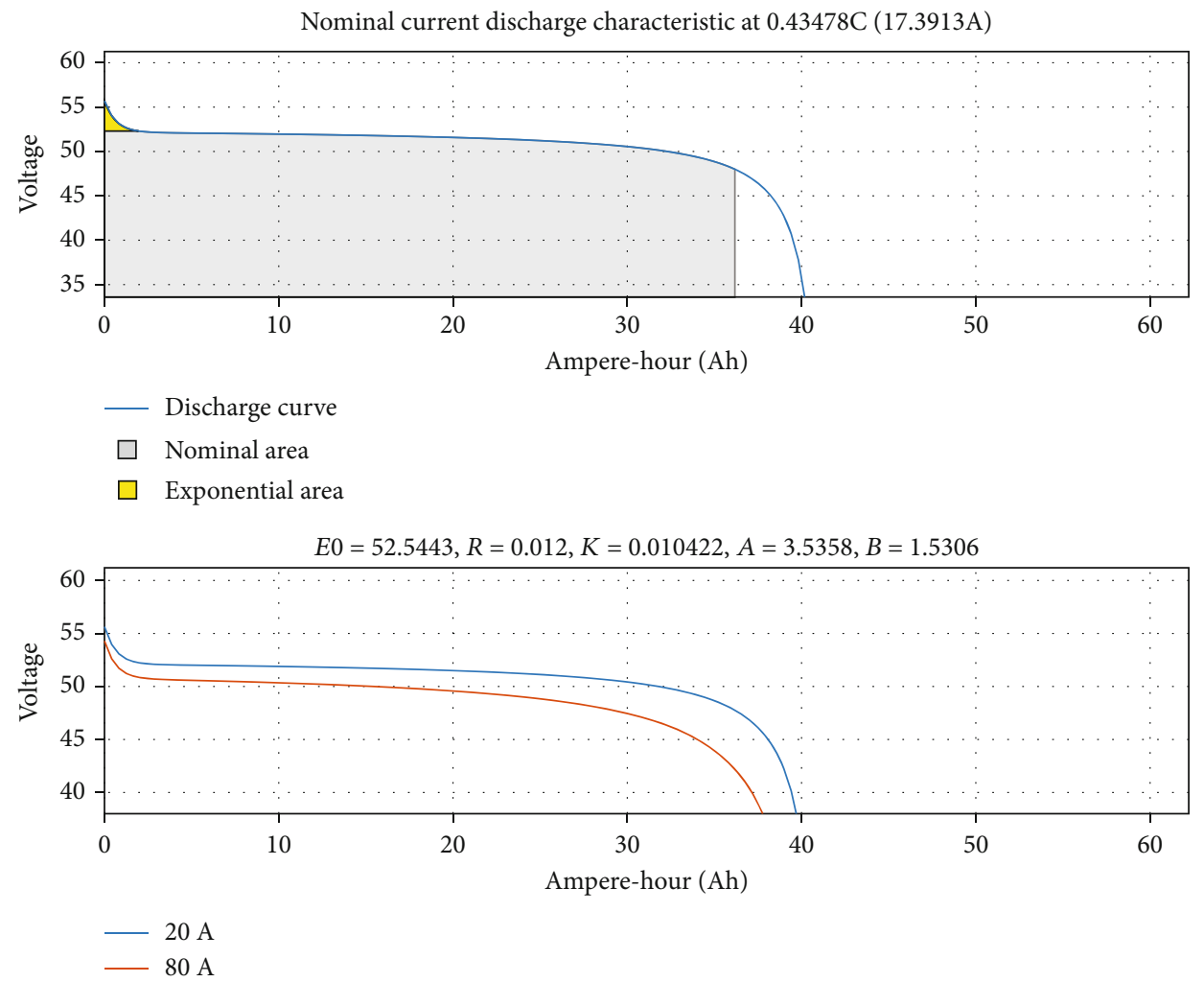

Figure 5: The dynamic behaviour of battery.

\section{Design and Dynamic Modelling of DC to DC Converter}

The fuel cell hybrid power system is designed based on the load profile of pseudosatellites which consist of the following: $12.5 \mathrm{~kW}$ (peak); 30-60 V PEM (proton exchange membrane) fuel cell power module (FCPM), with a nominal power of $10 \mathrm{~kW} ; 48 \mathrm{~V}, 40 \mathrm{Ah}, \mathrm{Li}$-ion battery system; $291.6 \mathrm{~V}, 15.6 \mathrm{~F}$, supercapacitor system $(6 \times 48.6 \mathrm{~V}$ cells in series); $12.5 \mathrm{~kW}$ fuel cell DC to DC boost converter, with regulated output voltage and input current limitation; two DC to DC converters for discharging ( $4 \mathrm{~kW}$ boost converter); and charging (1.2 kW buck converter) the battery system.

These converters are also output voltage regulated with current limitation. Normally, a single bidirectional DC to DC converter can also be used to reduce the weight of the power system [19, 22-24]. The fuel cell DC to DC converter system is $(30-60 \mathrm{~V}) \mathrm{DC}$ in $270 \mathrm{~V} \mathrm{DC}, 9.2 \mathrm{~A}$ the battery dc to dc converter system: it consists of 2, (40-58.4 V) DC in, $270 \mathrm{VDC}, 7 \mathrm{~A}$ out, dc to dc isolated boost converter connected in parallel. Together with 1, (243-297 V) DC in, $48 \mathrm{~V} \mathrm{DC}, 20 \mathrm{~A}$ (max.) out, DC to DC isolated buck converter.

DC to DC converters can be represented by two types of models, which are the switching models and the averagevalue model. In this case, the averaged-value model is used. The advantages of average value models are simulation speed, simulation complexity, and control design. In (Figure 7), DC to DC boost converter model in Simulink/SimPowerSystems (SPS) is presented [19].
TABLE 3: Supercapacitor model parameters.

\begin{tabular}{lc}
\hline Supercapacitor model input parameters & \\
\hline Rated capacitance (F) & {$[15.6]$} \\
Equivalent DC series resistance (ohms) & {$[0.15]$} \\
Rated voltage $(\mathrm{V})$ & {$[291.6]$} \\
Number of series capacitors & {$[108]$} \\
Number of parallel capacitors & {$[1]$} \\
Initial voltage & {$[270]$} \\
Operating temperature (celsius) & {$[25]$} \\
\hline
\end{tabular}

5.1. Power Management Strategy of HAPS. To ensure the fuel cell, battery, and supercapacitor system operate efficiently and within their respective constraints, an energy management system is necessary [21,25].

The main objectives of an energy management system are to guarantee the following: [19]:

(i) Low hydrogen consumption

(ii) Increased overall system efficiency

(iii) The battery SOC remains in a narrow operating range

(iv) Long life cycle

The objectives are achieved by controlling the power flow to each of the three sources in order to meet the load requirements through their associated converters, using an energy 


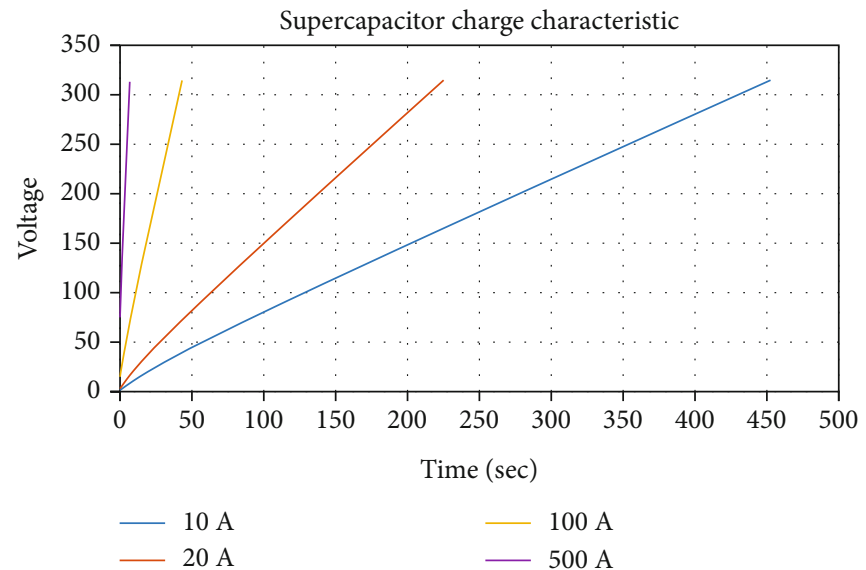

FIGURE 6: The supercapacitor charge characteristic.

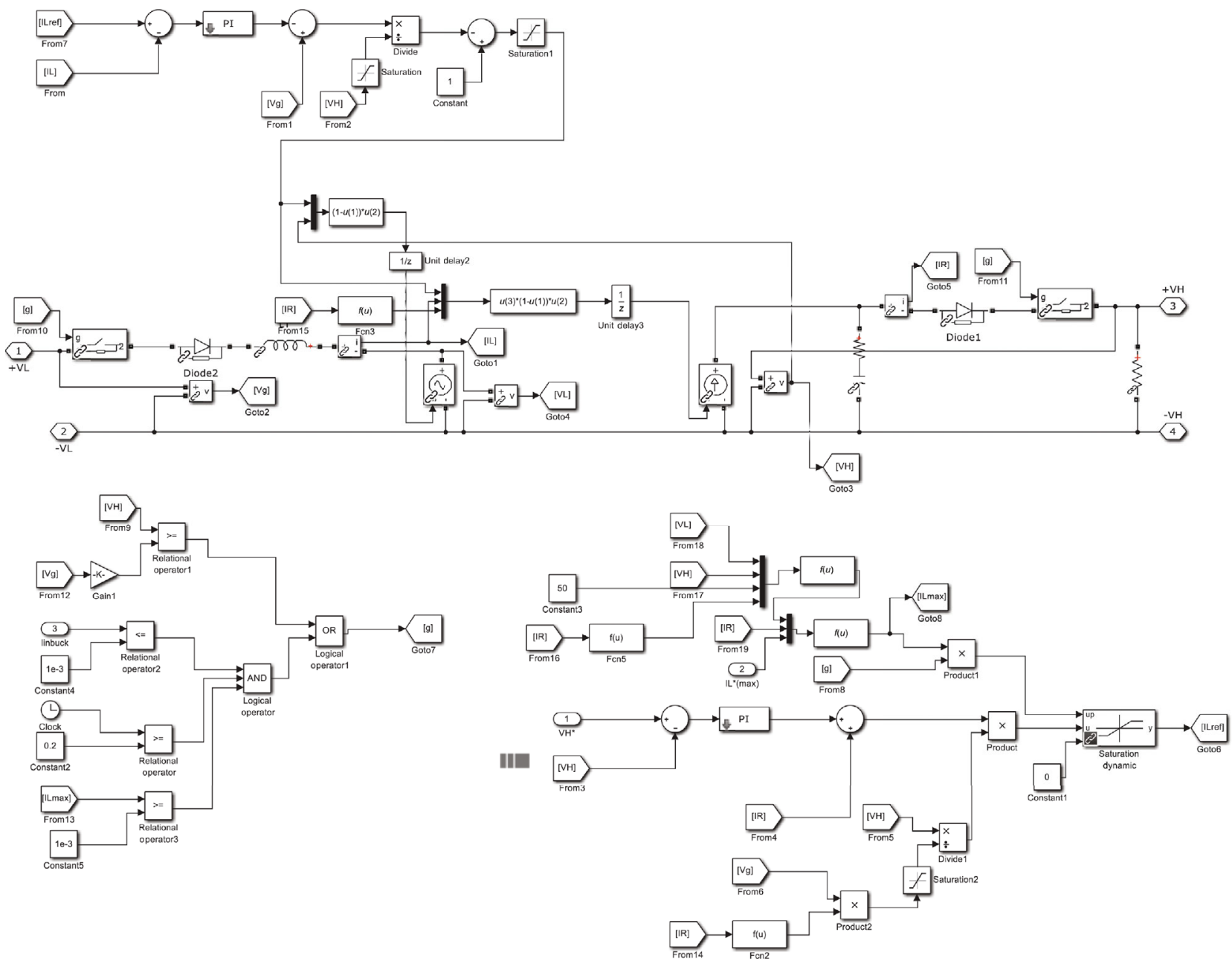

Figure 7: DC to DC boost converter model in Simulink/SimPowerSystems (SPS).

management strategy [13]. The energy management strategy is designed based on the following: to preserve the fuel cell lifetime by avoiding an insufficient supply of reactants (fuel cell starvation); the fuel cell current slope of $40 \mathrm{~A} / \mathrm{s}$; fuel cell power: $P f \mathrm{cmin}=1 \mathrm{~kW}$ and $P f \mathrm{cmax}=10 \mathrm{~kW}$; battery power:
PBattmin $=1.2 \mathrm{~kW}$ and PBattmax $=4 \mathrm{~kW}[13]$; also to operate the battery system efficiently, it is required to keep the battery SOC above $40 \%$ at all time. The fuel cell power is determined by the battery state of change and the required load power (Pload). The bus voltage is regulated through the battery 


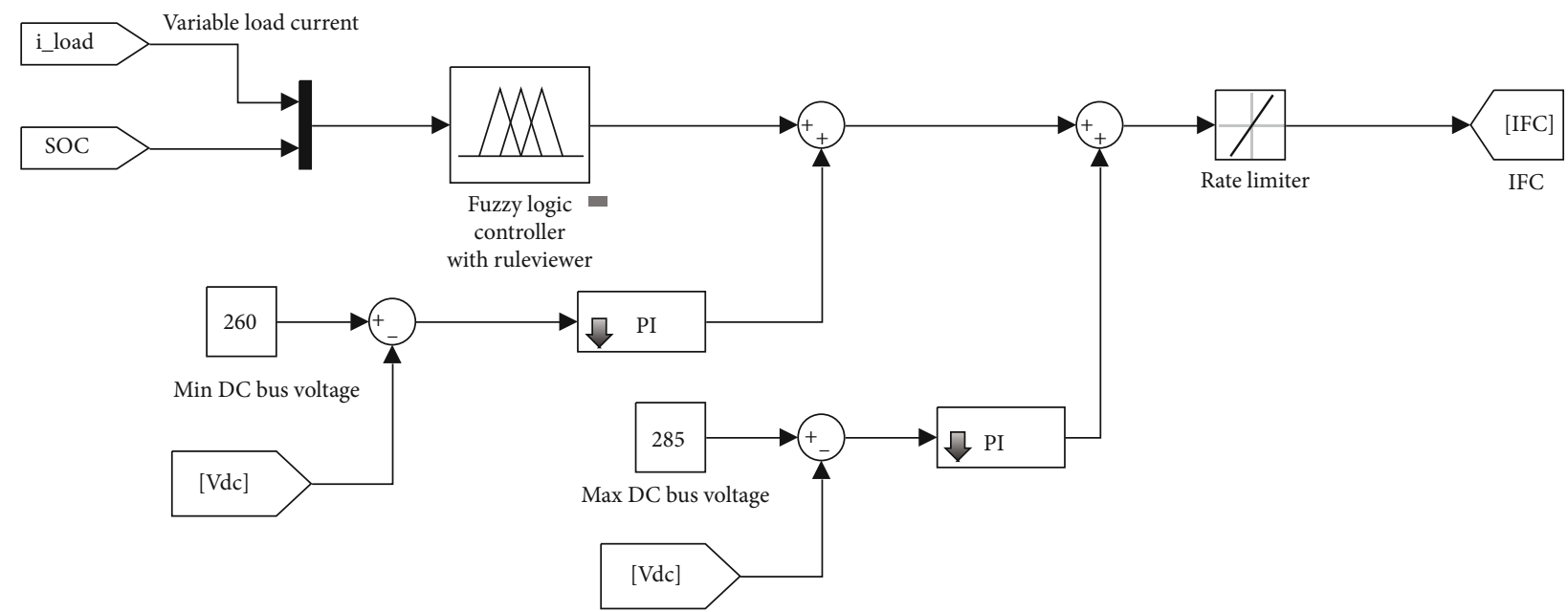

FIGURE 8: Schematic of the power management strategies.

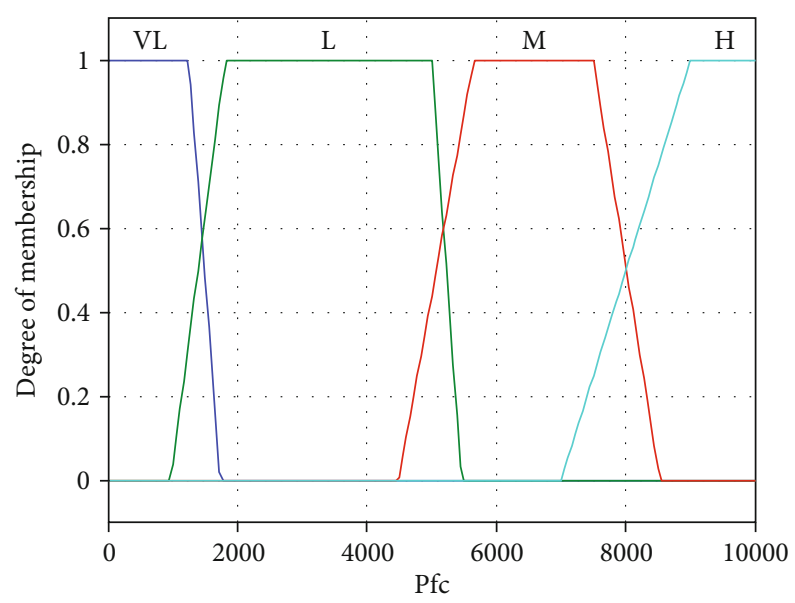

(a)

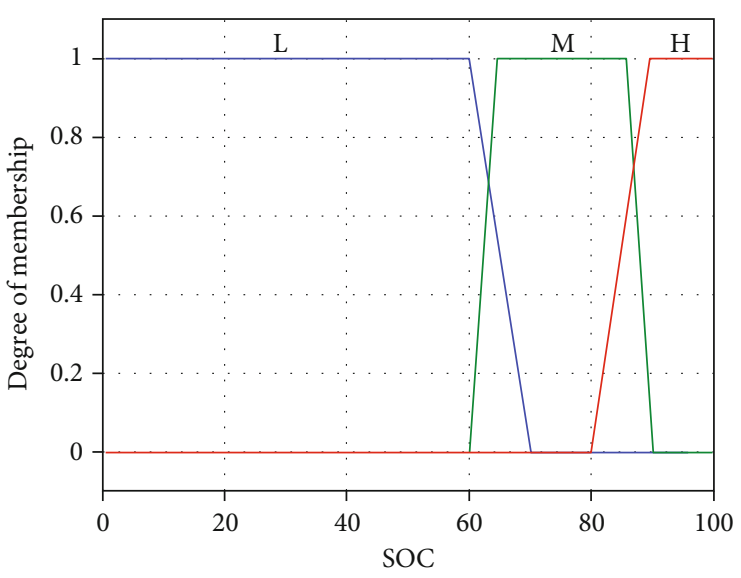

(b)

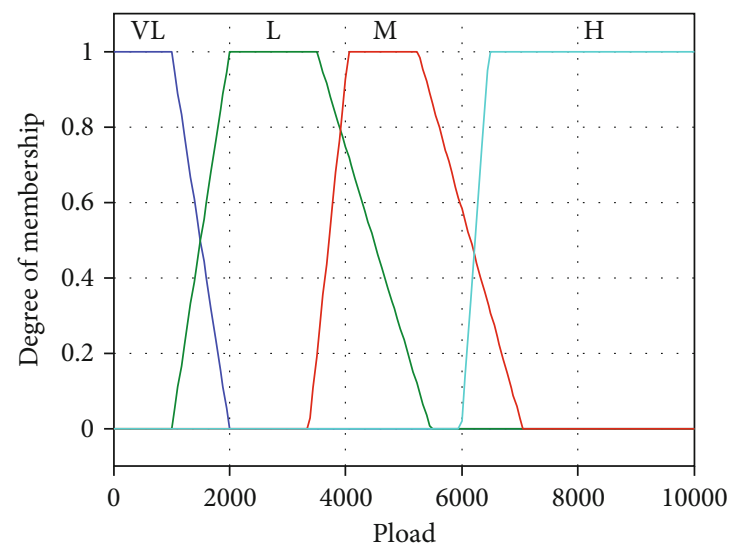

(c)

Figure 9: (a) Input 1 membership functions. (b) Input 2 membership functions. (c) Output membership functions.

converters for energy management system strategies. As shown in Figure 8, the output of the algorithm is the reference for fuel cell power. Both this quantity relative to the fuel cell voltage and the efficiency of the DC to DC converter lead to the value of the fuel cell reference current [21].
5.1.1. The Rule-Based Fuzzy Logic Strategy. The rule-based fuzzy logic strategy is implemented in SPS using Simulink Fuzzy Logic Controller block from Fuzzy Logic Toolbox. The structure of this Fuzzy Logic Controller (FLC) is designed with the help of the Fuzzy Inference Toolbox 


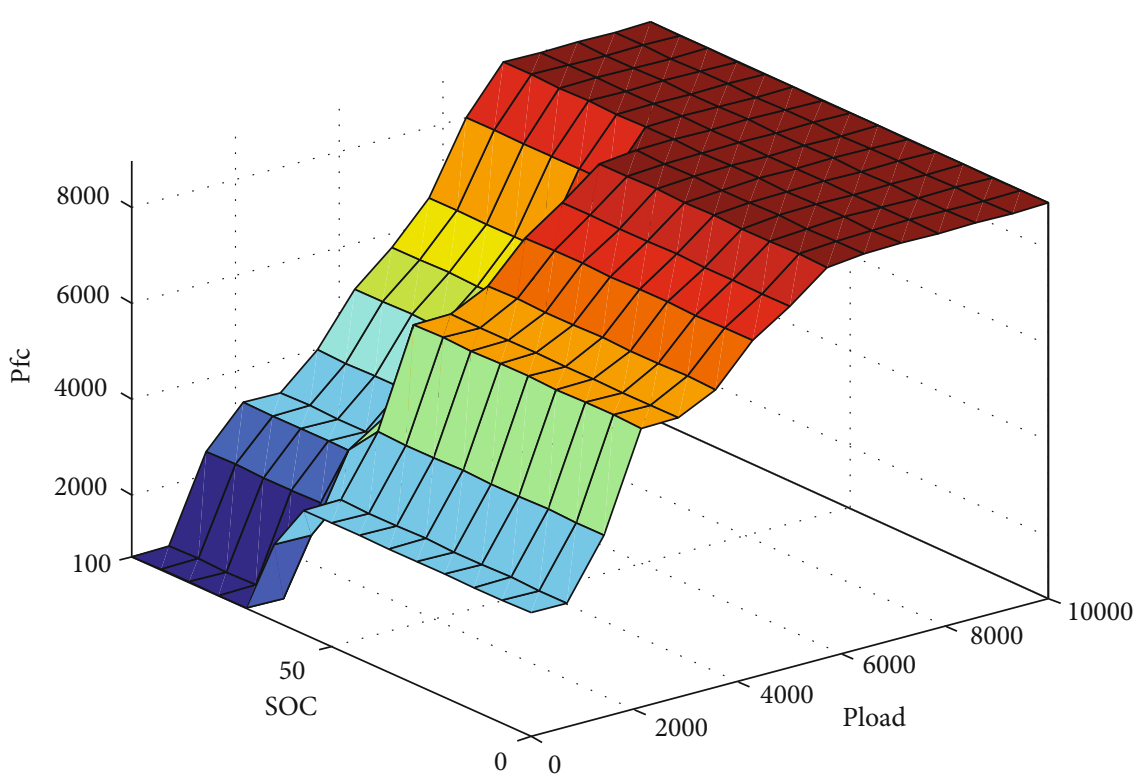

FIgURE 10: The control surface of the fuzzy logic controller.

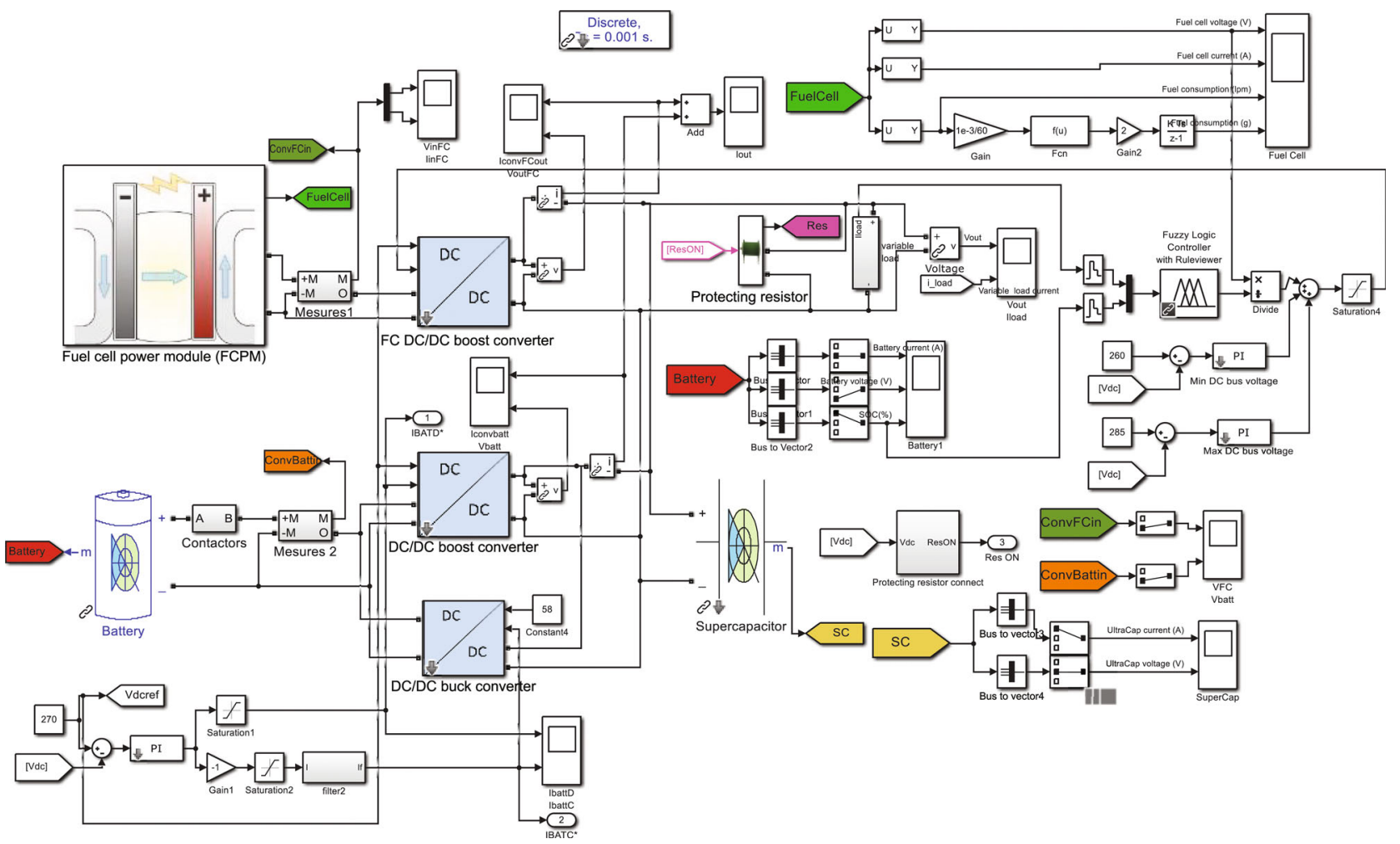

FIGURE 11: The whole hybrid system implemented in Matlab/Simulink.

(FIS) Editor Graphical User Interface (GUI) tool of Matlab [20]. The fuel cell power is obtained based on the load power and SOC membership functions and the set of if-then rules. The inputs of FLC are the load power (Pload) and battery SOC (the state-of-charge), and the output of FLC is the fuel cell power (PFC). Membership functions were considered trapezoidal, like in Figures 9(a)-9(c). The design is made following an approach similar to [20].
The linguistic terms for input 1 (Pload) are VL (Very Low), L (Low), M (Medium), H (High); for input 2 (SOC) are L (Low), M (Medium), $\mathrm{H}$ (High), and for the output are VL (Very Low), L (Low), M (Medium), and H (High). The fuzzy logic rules are as follows: if (Pload is VL) and (SOC is $\mathrm{H}$ ), then (PFC is VL); if (Pload is $\mathrm{L}$ ) and (SOC is $\mathrm{H}$ ), then (PFC is $\mathrm{L}$ ); if (Pload is M) and (SOC is $\mathrm{H}$ ), then (PFC is $\mathrm{M})$; if (Pload is $\mathrm{H}$ ) and (SOC is $\mathrm{H})$, then (PFC is $\mathrm{H}$ ); if (Pload 


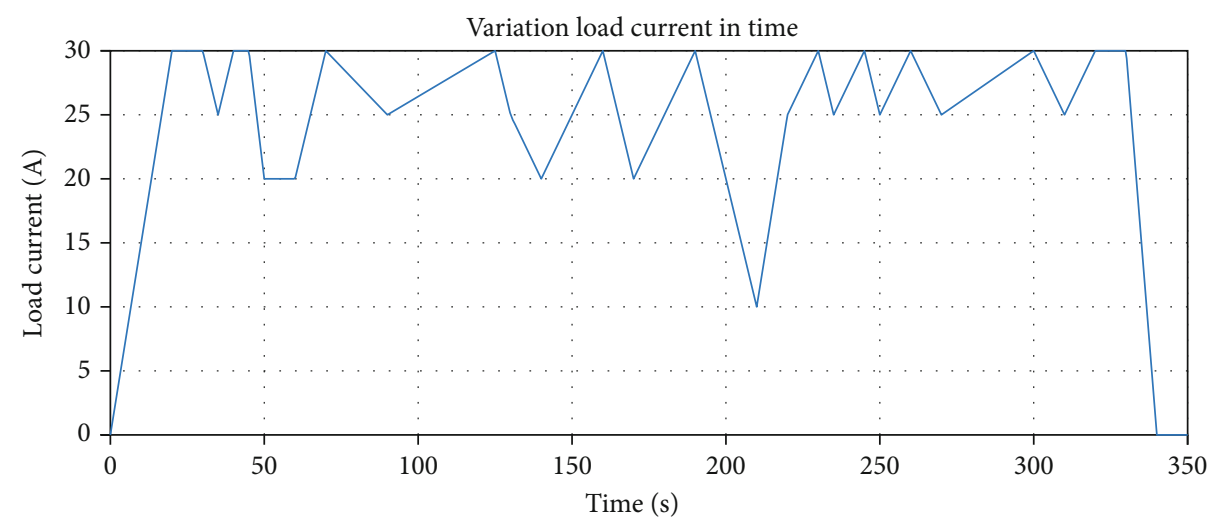

FIGURE 12: Load profile used in numerical simulations-case I.
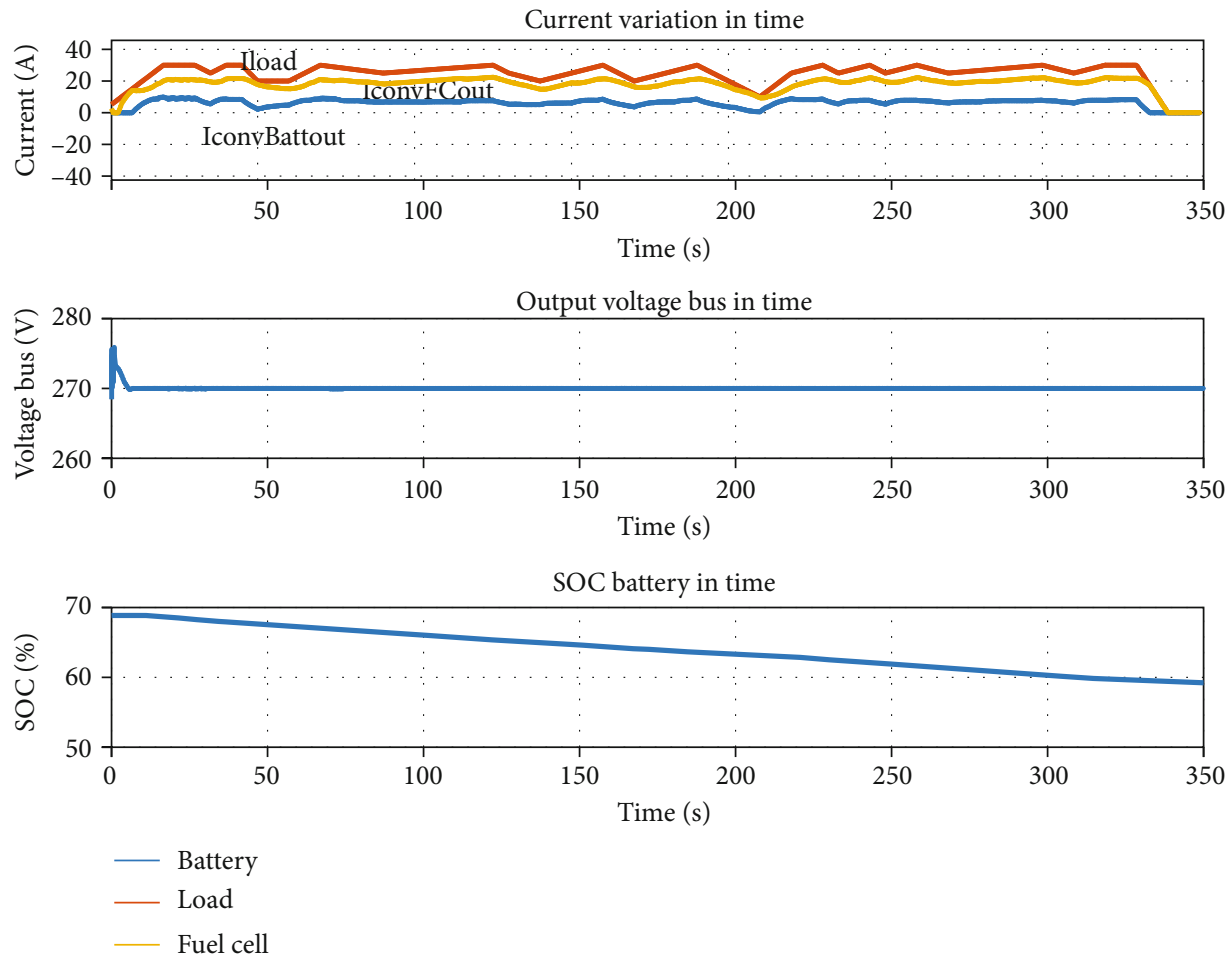

FIGURE 13: Simulation results for load profile used in case I.

is $\mathrm{VL}$ ) and ( $\mathrm{SOC}$ is $\mathrm{M})$, then (PFC is $\mathrm{VL})$; if (Pload is $\mathrm{L}$ ) and (SOC is $\mathrm{M})$, then (PFC is $\mathrm{L}$ ); if (Pload is $\mathrm{M}$ ) and (SOC is $\mathrm{M}$ ), then (PFC is M); if (Pload is $\mathrm{H}$ ) and (SOC is M), then (PFC is $\mathrm{H})$; if (Pload is VL) and (SOC is L), then (PFC is L); if (Pload is $\mathrm{L}$ ) and (SOC is $\mathrm{L})$, then (PFC is $\mathrm{M}$ ); if (Pload is $\mathrm{M}$ ) and (SOC is $\mathrm{L}$ ), then (PFC is $\mathrm{H}$ ); if (Pload is $\mathrm{M}$ ) and (SOC is $\mathrm{L}$ ), then (PFC is $\mathrm{H}$ ); and if (Pload is $\mathrm{H}$ ) and (SOC is $\mathrm{L}$ ), then (PFC is $\mathrm{H}$ ). The Mamdani fuzzy inference approach is used along with the centroid method for defuzzification (Figure 10).

5.2. Simulating the Fuel Cell Hybrid Power System in Matlab/Simulink. Figure 11 presented the whole hybrid system realized in Matlab/Simulink. The performance management schemes proposed in this paper were tested by numerical simulations. The energy management system block outputs are the control signals required by the DC to DC converter. The inputs to the energy management system are the load current, fuel cell, battery, and/or supercapacitor voltage and current, together with the battery SOC and the output current of each DC to DC converter. The management system was tested using two electric load profiles, presented in the next figures. Two random load profiles can be used to test the management systems. The hybrid power system consists of a $12.5 \mathrm{~kW}$ fuel cell power, with a nominal power of $10 \mathrm{~kW}$ along with $4 \mathrm{x} 12.8 \mathrm{~V}, 40$ Ah battery module and $6 \mathrm{x} 48.6 \mathrm{~V}, 15.6 \mathrm{~F}$ supercapacitor module. Also, the DC to DC converters were selected appropriately to match the power requirement. 


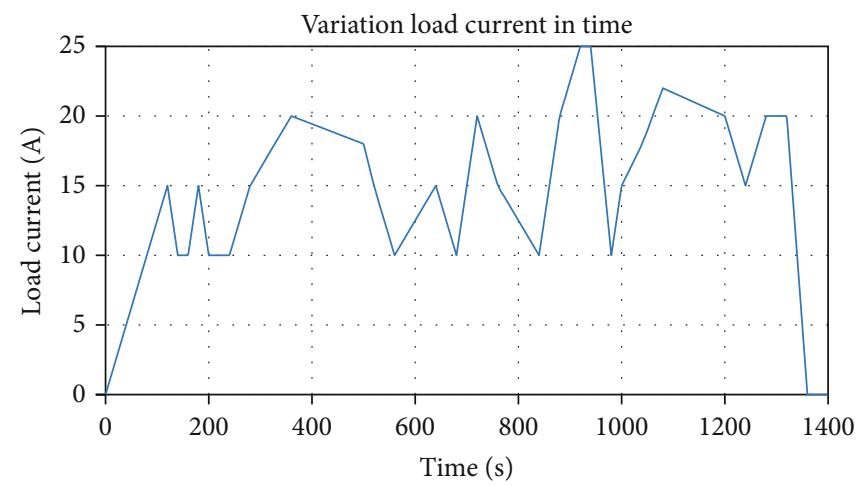

FIgURE 14: Load profile used in numerical simulations-case II.
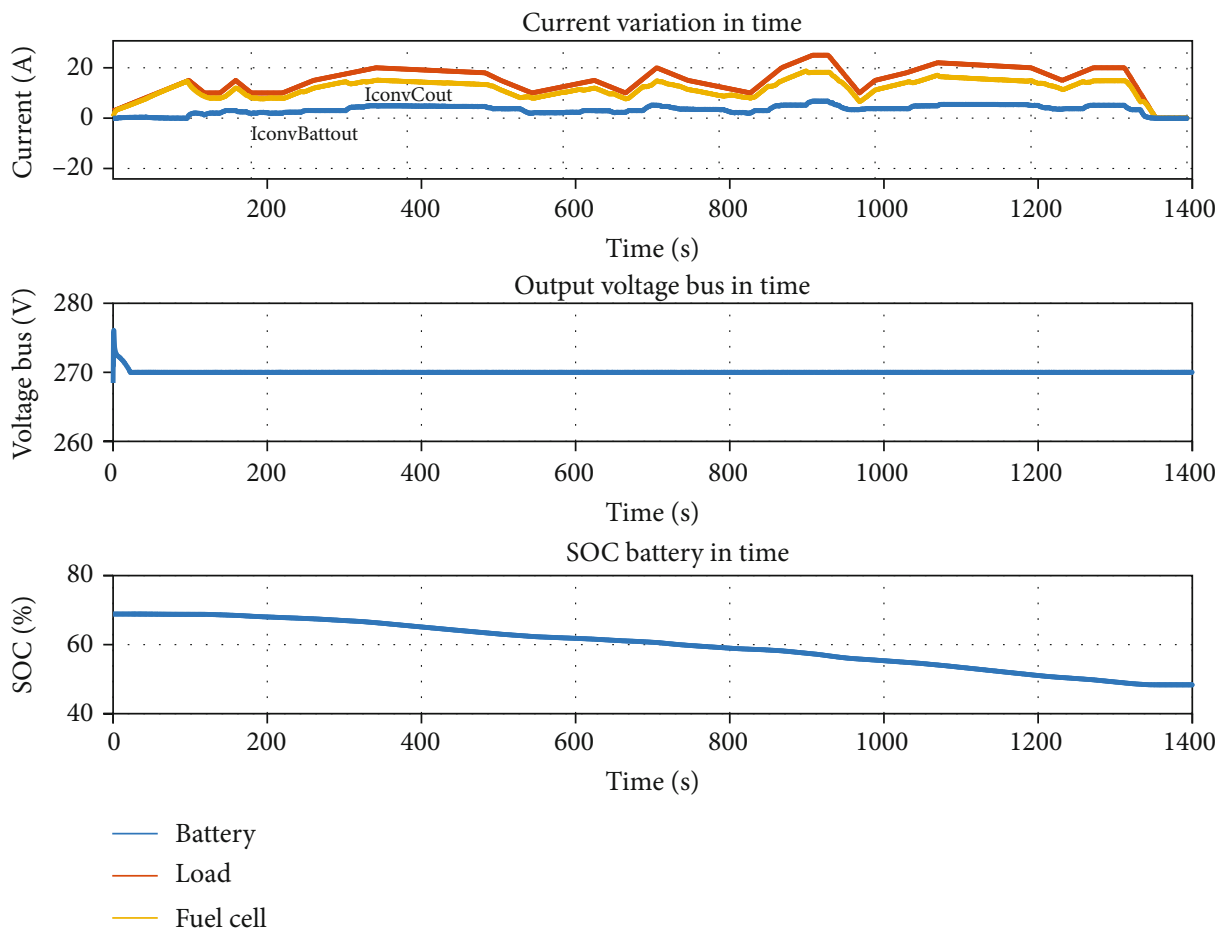

FIGURE 15: Simulation results for load profile used in case II.

The load profiles used in simulations for the first case are presented in Figure 12, and the simulation results are related in Figure 13; by analogy, for the second case, Figure 14 presented the load profile, and in Figure 15 the simulation results. The fuel cell current (in ampere) and the battery current (in ampere) at $270 \mathrm{~V}$ DC bus are shown in Figure 13 and Figure 15, for each of the two cases. The battery SOC in percentage is shown in Figure 13. The fuzzy logic control scheme ensures the fuel cell to provide a nearly constant current, which allows the battery to recharge. As it can be observed, this control scheme provides the usage of the battery energy, having SOC between 70 and 59\%. It is observed that the scheme has a faster response to load change. The fuel cell power is obtained based on the load power and SOC membership functions and the set of "ifthen rules."

\section{Conclusions}

This paper presented a study of the energy management scheme for a hybrid power source of pseudosatellites. Using the principle of complementary advantages, a possible energetic system on-board HAPS was designed. It contains as the main source of energy fuel cell and as secondary sources batteries and/or super-capacitors, along with associated DC to DC converters. The energy management scheme implemented an intelligent control technique constructed based on fuzzy logic control (FLC). A simulation is provided using Matlab/Simulink-based models. The simulation results are given to show the overall system performance. The power management control scheme proposed in this paper ensures that the system operates with high efficiency, keeping a very stable output bus voltage. 


\section{Data Availability}

The authors are willing to make available to those interested the results of the research presented in this article.

\section{Conflicts of Interest}

The authors declare that there is no conflict of interest regarding the publication of this paper.

\section{Acknowledgments}

This work is supported by a grant from the Ministry of National Education and Scientific Research, RDI Programe for Space Technology and Advanced Research - STAR, project number [155/20.07.2017].

\section{References}

[1] P. O'Neil, Boeing High Altitude Long Endurance (HALE UAS), Boeing Defense, Space\& Security, 2012.

[2] N. Owano, Titan Aerospace Readies Solar-Powered, LongEndurance UAVs, 2013.

[3] R. Müller, J. Kiam, and F. Mothes, "Multiphysical Simulation of a Semi-Autonomous Solar Powered High Altitude Pseudo-Satellite," in 2018 IEEE Aerospace Conference, pp. 16, Big Sky, MT, USA, 2018.

[4] "Phantom Eye Technical Specifications," http://www.boeing .com/defense/phantom-eye/.

[5] The Zephyr High Altitude Pseudo-Satellite Aircraft.

[6] H. Ross, EWADE, Sevilla, 2009, http://www.solarimpulse.com.

[7] Environmentally friendly, Inter City Aircraft powered by Fuel Cells, European (6th RTD Framework Programme), ENFICAFC, 2010, Grant agreement ID: 30779, 1 October 2006-30 June 2010.

[8] R. K. Agarwal, Review of Technologies to Achieve Sustainable (Green) Aviation. Recent Advances in Aircraft Technology, Publisher InTech, 2012.

[9] J. Kallo, G. Renouard-Vallet, M. Saballus, G. Schmithals, J. Schirmer, and K. A. Friedrich, "Fuel Cell System Development and Testing for Aircraft Applications," in 18th World Hydrogen Energy Conference, pp. 435-444, Proceedings of the WHEC, 2010.

[10] P. Rathhe, O. Thalau, J. Kallo, J. Schirmer, and T. Stephan, Long Distance Flight Testing with Fuel Cell Powered Aircraft ANTARES DLR-H2, Deutscher Luft-und Raumfahrtkongress, 2013.

[11] J. I. Corcau, L. Dinca, T. L. Grigorie, and E. Ureche, "Hybrid power source for pseudo-satellites," in International Multidisciplinary Scientific GeoConference: SGEM, pp. 329-336, Bulgaria, 2017.

[12] G. M. Arregui, Theoretical Study of a Power Generation Unit Based on the Hybridization of a Fuel Cell Stack and Ultracapacitors. Application to the Design of an Aircraft Emergency Electrical Network, THĖSE Présentée pour obtenir le titre de Doctorat De L'universite De Toulouse, 2007.

[13] I. Aschilean, M. Varlam, M. Culcer et al., "Hybrid electric powertrain with fuel cells for a series vehicle," Energies, vol. 11, no. 5, 2018.

[14] H. Zhang, M. Zhou, and X. Lan, "State of charge estimation algorithm for unmanned aerial vehicle power-type lithium battery packs based on the extended Kalman filter," Energies, vol. 12, no. 20, 2019.

[15] S. Motapon, L. A. Dessaint, and K. A. Al-Haddad, Comparative Study of Energy Management Schemes for a Fuel Cell Hybrid Emergency Power System of More Electric Aircraft, IEEE Transactions on Industrial Electronics, 2012.

[16] 2001, http://www.fuelcells.org.

[17] J. Larminie and A. Dicks, Fuel cell systems explained, Wiley, Second Edition edition, 2003, ISBN 0-470-84857-X.

[18] S. Carlier, A. Celikel, and N. Duchene, Potential Benefits of Fuel Cell Usage in the Aviation Context, GAES project, 2006.

[19] S. N. Motapon, Design and Simulation of a Fuel Cell Hybrid Emergency Power System for a More Electric Aircraft: Evaluation of Energy Management Schemes, École de technologie supérieure, 2013.

[20] J. I. Corcau, L. Dinca, T. L. Grigorie, and A. N. Tudosie, "Fuzzy energy management for hybrid fuel cell/battery systems for more electric aircraft," AIP Conference Proceedings, vol. 1836, pp. 1-8, 2017.

[21] D. Wu, Control of a Super-Capacitor Based Energy Storage System, School of Electrical and Electronic Engineering, 2013.

[22] X. Zheng, H. Ali, X. Wu, Z. Haider, and S. Khan, "Non-linear behavioral modeling for DC-DC converters and dynamic analysis of distributed energy systems," Energies, vol. 10, no. 1, p. 63, 2017.

[23] L. Arnedo, D. Boroyevich, R. Burgos, and F. Wang, "Polytopic black-box modeling of DC-DC converters," in 2008 IEEE Power Electronics Specialists Conference, pp. 1015-1021, Rhodes, Greece, 2008

[24] Y. Huangfu, S. Pang, B. Nahid-Mobarakeh, A. Rathore, F. Gao, and D. Zhao, "Analysis and design of an active stabilizer for a boost power converter system,” Energies, vol. 9, no. 11, p. 934, 2016.

[25] Ó. González-Espasandín, T. J. Leo, and E. Navarro-Arévalo, "Fuel cells: a real option for unmanned aerial vehicles propulsion," The Scientific World Journal, vol. 2014, Article ID 497642, 12 pages, 2014. 